\title{
Pengaruh Model Pembelajaran Example Non Example dan Motivasi Belajar Siswa terhadap Keterampilan Menulis Teks Prosedur
}

\section{The Effect of Example Non Example Learning Model and Student's Learning Motivation on Procedure Text Writing Skills}

\author{
Lasri Maisa Putri1,* dan Syahrul Ramadhan ${ }^{2}$ \\ 1,2 Bahasa dan Sastra Indonesia, FBS, Universitas Negeri Padang, Padang, Sumatera Barat, Indonesia \\ 1,^ Email: lasrimaisa.0507@gmail.com; Orcid: https://orcid.org/0000-0002-2935-7121 \\ 2Email: syahrulramadhan.532@gmail.com; Orcid: https://orcid.org/0000-0001-5461-1374
}

\begin{abstract}
ARTICLE HISTORY
Received 27 October 2021

Accepted 15 November 2021

Published 1 February 2022

KEYWORDS

learning model, learning motivation, procedure text.

\section{KATA KUNCI}

model pembelajaran, motivasi belajar, teks prosedur.

ABSTRACT

This experimental research was motivated by a problem in learning Indonesian: the low score of students' learning outcomes in writing procedural texts. Based on this, this research was conducted to know the effect of the Example Non Example learning model and learning motivation on the skills of writing procedure text. The samples of this study were students in grade 7-I (experimental class) and grade 7- $\mathrm{H}$ (control class) at MTs Negeri 4 Pasaman Barat for the academic year 2020/2021. The data of this research are the score of the learning motivation questionnaire and the test scores for writing procedural text writing skills in the experimental and control classes. The final results of this study indicate that the Example Non Example learning model has a good effect on the writing skills of the seventh-grade students of MTs Negeri 4 Pasaman Barat. It can be seen from the scores of students' procedural text writing skills taught using the Example Non Example cooperative learning model better than students taught using conventional learning models. Furthermore, there is also an interaction between the Example Non-Example learning model and learning motivation so that students can write procedure texts better.

\section{ABSTRAK}

Penelitian eksperimen ini dilatarbelakangi adanya masalah dalam pembelajaran bahasa Indonesia, yaitu rendahnya nilai hasil belajar menulis teks prosedur siswa. Berdasarkan hal tersebut penelitian ini dilakukan dengan tujuan untuk mengetahui pengaruh model pembelajaran Example Non Example dan motivasi belajar terhadap keterampilan menulis teks prosedur siswa SMP/MTs kelas VII. Sampel penelitian ini adalah siswa kelas 7-I (kelas eksperimen) dan siswa kelas 7-H (kelas kontrol) MTs Negeri 4 Pasaman Barat tahun pelajaran 2020/2021. Data penelitian ini adalah skor angket motivasi belajar dan skor nilai tes unjuk kerja keterampilan menulis teks prosedur pada kelas eksperimen dan kelas kontrol. Hasil akhir penelitian ini menunjukkan bahwa model pembelajaran Example Non Example berpengaruh baik terhadap keterampilan menulis teks prosedur siswa kelas VII MTs Negeri 4 Pasaman Barat. Hal ini dapat dilihat dari skor nilai keterampilan menulis teks prosedur siswa yang diajar dengan menggunakan model pembelajaran kooperatif tipe Example Non Example lebih baik daripada siswa yang diajar menggunakan model pembelajaran konvensional. Selanjutnya, juga terdapat interaksi antara model pembelajaran Example Non Example dengan motivasi belajar sehingga mengakibatkan siswa mampu menulis teks prosedur lebih baik.
\end{abstract}

To cite this article:

Putri, L. M., \& Ramadhan, S. (2022). Pengaruh Model Pembelajaran Example Non Example dan Motivasi Belajar Siswa terhadap Keterampilan Menulis Teks Prosedur. Diglosia: Jurnal Kajian Bahasa, Sastra, dan Pengajarannya, 5(1), 13-30. https://doi.org/10.30872/diglosia.v5i1.316 


\section{A. Pendahuluan}

Keterampilan menulis adalah sebuah kemampuan membangun kalimat yang benar sesuai dengan tata bahasa sehingga maknanya dapat dipahami oleh pembaca (Negari, 2011). Keterampilan menulis merupakan bagian penting dari proses komunikasi. Dalam proses komunikasi tersebut, seseorang dapat mengekspresikan pikiran, perasaan dan pendapat secara tertulis (Anh, 2019). Dengan demikian, dapat disimpulkan bahwa menulis merupakan salah satu kegiatan yang bermanfaat dalam kehidupan sehari-hari, khususnya dalam kegiatan pembelajaran di sekolah karena siswa akan banyak melakukan kegiatan baik di dalam maupun di luar pembelajaran. Selain itu, siswa juga dapat berpikir kritis, kreatif, dan inovatif dalam menuangkan ide, gagasan, perasaannya ke dalam sebuah tulisan. Dalam kegiatan pembelajaran, kegiatan menulis ini sangat penting dipelajari oleh siswa.

Pentingnya kegiatan menulis ini menyebabkan banyak peneliti melakukan penelitian tentang keterampilan menulis termasuk peneliti dari beberapa negara di luar Indonesia. Karunasree \& Francis (2020) yang menyatakan bahwa keterampilan menulis penting dipelajari oleh setiap siswa karena dapat membuka kesempatan yang lebih luas untuk melanjutkan pendidikan tingkat tinggi atau serta kesempatan untuk mendapatkan peluang kerja. Selain itu, Queroda (2018) juga mengungkapkan bahwa keterampilan menulis juga dapat memberikan kontribusi khusus terhadap cara berpikir seseorang karena melalui kegiatan menulis ini seseorang dapat mengumpulkan ide berdasarkan fakta yang ditemukan sehingga dapat menghasilkan sesuatu yang baru. Pentingnya keterampilan menulis menurut Javed et al. (2013) dapat meningkatkan eksposur dan kompetensi siswa untuk mencapai tujuan komunikasi dan interaksi.

Selanjutnya, dalam penelitian-penelitian tersebut ditemukan masalahmasalah mengenai kemampuan menulis. Masalah utama yang dialami siswa adalah suasana kelas yang padat dan berisik sehingga mengganggu konsentrasi siswa dalam kegiatan belajar (Queroda, 2018) dan kurangnya minat siswa dalam menguasai keterampilan menulis karena pengaruh negatif kemajuan teknologi, seperti ketersediaan tugas yang sudah jadi sehingga siswa menjadi malas untuk belajar mandiri (Muslim, 2014). Hal tersebut membuat siswa kesulitan menulis karena keterbatasan kosa kata, kesulitan menggunakan tata bahasa, dan tidak dapat menerapkan strategi menulis yang fleksibel secara efektif (Anh, 2019). Selain itu, metode atau cara mengajar guru juga dapat mempengaruhi semangat belajar siswa dan kemampuan menulis siswa (Javed et al., 2013). Sementara itu peneliti-peneliti Indonesia juga menemukan permasalahan yang sama, yaitu rendahnya keterampilan menulis siswa. Keterampilan menulis tersebut terdapat dalam pelajaran Bahasa Indonesia, salah satunya adalah menulis teks prosedur pada kelas VII.

Teks prosedur merupakan bagian dari teks kebahasaan berisi langkahlangkah yang harus dilakukan untuk mencapai tujuan secara lengkap dan detail. Pembelajaran teks prosedur ini harus dipahami oleh siswa dengan baik terutama bagian struktur teks, isi teks, ciri-ciri teks, dan cara menulis teks prosedur. Selain itu, guru yang memiliki peran penting dalam pembelajaran ini juga dituntut untuk 
menggunakan model pembelajaran dan strategi pembelajaran yang tepat agar pembelajaran lebih mudah diterima dan dipahami oleh siswa sehingga siswa mampu menggali kreativitasnya dalam menulis teks prosedur (Aminah, 2020; Hidayat, 2020; Kartikasari \& Khotimah, 2018; Lestari, Dian, \& Sudrajat, 2018; Mandasari, Atmazaki, \& Noveria, 2017; Utama, 2019; Zurita, Thahar, \& Thamsin, 2017).

Berdasarkan hasil wawancara yang dilakukan pada 10 Novembar 2020 dengan salah satu guru bahasa Indonesia kelas VII MTs Negeri 4 Pasaman Barat bernama Elin Nofia Jumesa, S.Pd. diperoleh informasi tentang permasalahan siswa dalam menulis teks prosedur sehingga nilai yang diperoleh masih rendah dan belum memenuhi Kriteria Ketuntasan Minimal (KKM), yaitu 75. Permasalahan tersebut dipengaruhi oleh beberapa faktor, yaitu: Pertama, siswa kesulitan menemukan ide-ide dalam menulis teks prosedur. Kedua, siswa kesulitan memahami struktur dan ciri kebahasaan teks prosedur. Ketiga, siswa kurang memahami tentang penggunaan kalimat efektif dan EBI (tanda baca, penulisan kata, dan penggunaan huruf kapital). Keempat, rendahnya motivasi siswa dalam belajar. Permasalahan dalam menulis teks prosedur lainnya ditemukan dalam penelitian (Hapsari \& Wulandari, 2020) bahwa siswa mengalami kesulitan dalam memahami pelajaran bahasa berbentuk teks dan juga mengalami kesulitan menuangkan ide dalam bentuk tulisan, sedangkan dalam penelitian (Devi, Hudiyono, \& Mulawarman, 2018) ditemukan masalah penggunaan metode dan model pembelajaran yang kurang tepat sehingga siswa tidak memahami materi pelajaran dengan baik dan juga dapat membuat siswa merasa bosan serta motivasi belajar siswa juga menurun.

Salah satu upaya meningkatkan minat dan motivasi siswa dalam menulis teks prosedur adalah dengan menggunakan berbagai model pembelajaran kooperatif, yaitu pembelajaran kooperatif lainnya yang dapat digunakan dalam penelitian ini adalah model pembelajaran kooperatif tipe Example Non Example. Model pembelajaran ini merupakan salah satu model pembelajaran yang menarik dan kreatif sehingga dapat menarik minat siswa menulis teks prosedur. Selanjutnya, (Nawawi, Rahmayanti, \& Kasih, 2018; Sauri, 2018) dalam penelitiannya dijelaskan bahwa model pembelajaran Example Non Example menggunakan gambar sebagai medianya yang diharapkan dapat merangsang siswa lebih kreatif dalam mendapatkan ide karena siswa dituntut untuk menulis teks berdasarkan gambar yang disajikan. Selanjutnya, dalam pembelajaran menulis yang menggunakan model pembelajaran Example Non Example ini membuat dapat siswa saling berinteraksi, bersosialisasi, bertukar pikiran secara berkelompok sehingga dapat merangsang daya ingat siswa dan mendorong siswa untuk berpikir kritis dalam menyelesaikan masalah.

Beberapa peneliti sebelumnya yang telah menggunakan model pembelajaran Example Non Example dalam berbagai pembelajaran mengungkapkan bahwa model pembelajaran ini dapat meningkatkan keterampilan menulis siswa. Suryana (2017) dalam penelitiannya menjelaskan bahwa model pembelajaran Example Non Example memiliki peran yang sangat penting dalam meningkatkan kemampuan menulis karangan narasi siswa kelas V SDN Siayuh Kecamatan Kelumpang Barat Kabupaten Kotobaru. Nawawi, 
Rahmayanti, \& Kasih (2018) dalam penelitiannya juga membuktikan bahwa model pembelajaran Example Non Example juga berpengaruh terhadap kemampuan menulis puisi kelas X SMK Jakarta Manajemen. Hasil penelitian menunjukkan bahwa terdapat pengaruh yang signifikan antara hasil siswa sebelum diberi perlakuan (pretest) dengan yang sudah diberi perlakuan (posttest) pada keterampilan menulis puisi siswa.

Perbedaan penelitian-penelitian tersebut dengan penelitian ini adalah variabel yang akan diteliti dan populasi penelitian. Variabel yang digunakan dalam penelitian ini adalah keterampilan menulis teks prosedur sebagai variabel terikat, sedangkan variabel moderator yang digunakan adalah motivasi belajar. Populasi dari penelitian yang akan peneliti lakukan adalah siswa kelas VII MTs Negeri 4 Pasaman Barat.

Faktor lain yang juga dapat mempengaruhi keterampilan menulis teks prosedur adalah motivasi belajar. Motivasi dapat diartikan sebagai kekuatan seseorang yang dapat menimbulkan tingkat kemauan dalam suatu kegiatan (Suprihatin, 2015). Kemauan tersebut bersumber dari dalam diri individu (motivasi intrinsik) dan juga bersumber dari luar individu (motivasi ekstrinsik). Motivasi belajar berpengaruh besar terhadap hasil belajar siswa. Semakin tinggi motivasi siswa dalam belajar, umumnya semakin tinggi pula nilai hasil belajar yang diperoleh siswa (Muhammad, 2016; Wahyuni, Djatmika, \& As'sari, 2018). Sementara itu, cara menumbuhkan motivasi dalam diri siswa adalah dengan kekreatifan guru dalam memberikan stimulan kepada siswa, seperti memberi angka, hadiah, kompetisi, ego involvement, ulangan, mengetahui hasil, pujian, hukuman, hasrat belajar, minat, dan tujuan yang diakui (Oktiani, 2017).

\section{B. Metode}

Penelitian ini merupakan jenis penelitian eksperimen. Rancangan yang digunakan adalah rancangan eksperimen semu. Tujuan penelitian ini adalah untuk mengetahui pengaruh model pembelajaran kooperatif tipe Example Non Example motivasi belajar siswa terhadap keterampilan menulis teks prosedur siswa kelas VII MTs Negeri 4 Pasaman Barat. Populasi penelitian ini adalah seluruh siswa kelas VII MTs Negeri 4 Pasaman Barat yang terdaftar tahun ajaran 2020/2021. Siswa kelas VII tersebut tersebar ke dalam 9 kelas dengan jumlah 305 orang. Dikarenakan jumlah populasi besar dan lebih dari 100, perlu dilakukan pengambilan sampel. Oleh karena itu, penelitian ini hanya menggunakan dua kelas yang akan ditetapkan sebagai sampel penelitian, yaitu kelas eksperimen dan kelas kontrol. Kelas yang dipilih untuk kelas eksperimen adalah kelas 7-I yang berjumlah 36 orang siswa dan kelas yang dipilih untuk kelas kontrol adalah kelas $7-\mathrm{H}$ yang berjumlah 37 orang siswa. Kelas $7-\mathrm{H}$ dan kelas $7-\mathrm{I}$ adalah kelas yang paling homogen karena memiliki standar deviasi terendah dibandingkan dengan kelas lainnya dan kedua kelas tersebut merupakan kelas yang direkomendasikan guru untuk melakukan penelitian keterampilan menulis teks prosedur karena siswa di kelas ini memiliki kemampuan hampir sama.

Teknik pengumpulan data yang digunakan dalam penelitian ini menggunakan angket motivasi belajar dan tes unjuk kerja. Instrumen angket 
motivasi belajar diberikan kepada siswa kelas kontrol dan kelas eksperimen untuk mendapatkan data siswa yang mempunyai motivasi belajar tinggi dan motivasi belajar rendah. Sebelum digunakan, instrumen angket motivasi belajar ini terlebih dahulu divalidasi dan diujicobakan. Tes unjuk kerja ini juga diberikan kepada siswa kelas kontrol dan kelas eksperimen untuk mengetahui keterampilan menulis teks prosedur siswa. Teknik analisis data adalah teknik analisis deskriptif. Data yang dianalisis meliputi angket motivasi belajar dan tes unjuk kerja keterampilan menulis teks prosedur siswa kelas VII MTs Negeri 4 Pasaman Barat, sedangkan uji persyaratan analisis data yang dilakukan dalam penelitian ini adalah uji normalitas data, uji homogenitas data, dan uji hipotesis data.

Uji normalitas pada penelitian ini menggunakan uji Liliefors yang membandingkan $L_{0}$ dengan nilai kritis $L$ untuk menerima atau menolak hipotesis nilai $L_{0}$ yang diperoleh dengan dibandingkan dengan nilai $L$ pada tabel. Apabila $L_{0}<L_{t}$, maka data berdistribusi normal. Uji homogenitas ini dilakukan menggunakan rumus perbandingan varians terbesar dengan terkecil, kemudian membandingkan harga $F_{\text {hitung }}$ dengan $F_{\text {tabel }}$ yang terdapat pada daftar distribusi $F$ dengan taraf signifikan $5 \%$ dan $d k$ pembilang $\left(n_{1}+n_{2}\right)-2$. Apabila $F_{h}$ lebih kecil dari $F_{t}$ maka kedua kelompok data mempunyai varians homogen. Sebaliknya, jika $F_{h}$ lebih besar dari $F_{t}$ berarti kedua kelompok data memiliki varian tidak homogen.

Pengujian hipotesis 1 , hipotesis 2 , dan hipotesis 3 menggunakan analisis parsial (uji t), sedangkan pengujian hipotesis 4 menggunakan analisis varians anava dua jalur (uji F). Kriteria pengujian adalah menerima $\mathrm{Ho}$ jika $-t_{1-\frac{1}{2} \alpha}<t<$ $t_{1-\frac{1}{2} \alpha}$ di mana $t_{1-\frac{1}{2} \alpha}$ diperoleh dari distribusi $t$ dengan $d k=\left(n_{1}+n_{2}-2\right)$ dan peluang $\left(1-\frac{1}{2} \alpha\right)$. Selanjutnya, pengujian hipotesis 4 dilakukan dengan menggunakan analisis varians anova dua arah atau uji $\mathrm{F}$.

\section{Pembahasan}

Pada bagian pembahasan ini terdapat dua komponen yang dideskripsikan secara rinci, yaitu hasil penelitian dan uji persyarat analisis.

\section{Hasil Penelitian}

Penelitian ini dilakukan mulai tanggal 17 Mei sampai tanggal 31 Juli 2021. Kegiatan penelitian yang dilakukan adalah pengisian angket motivasi belajar, merencanakan pembelajaran, menyusun RPP dan bahan ajar, melaksanakan pembelajaran, mengumpulkan data, serta melakukan evaluasi terhadap data dikumpulkan. Jumlah sampel pada kelas eksperimen adalah 36 siswa dan jumlah sampel pada kelas kontrol adalah 37. Skor motivasi belajar siswa kelas eksperimen yang tertinggi sebesar 151 dan yang terendah 107, sedangkan pada kelas kontrol skor motivasi belajar yang tertinggi adalah 143 dan yang terendah 93. 
Berdasarkan analisis angket motivasi belajar siswa diperoleh 27\% dari 36 orang siswa, yaitu 10 orang siswa berada pada urutan paling atas yang memiliki motivasi belajar tinggi dan 10 orang siswa berada pada urutan paling bawah yang memiliki motivasi belajar rendah. Skor tertinggi diperoleh siswa yang memiliki motivasi belajar tinggi dengan perolehan skor tertinggi 151 dan skor terendah 137, sedangkan skor terendah diperoleh siswa yang memiliki motivasi belajar rendah memperoleh skor tertinggi 126 dan skor terendah 107. Sementara itu, jumlah sampel pada kelas kontrol adalah 37 orang siswa. Berdasarkan analisis angket motivasi belajar siswa pada kelas kontrol diperoleh $27 \%$ dari 37 orang siswa, yaitu 10 orang siswa berada pada urutan paling atas yang memiliki motivasi belajar tinggi dan 10 orang siswa berada pada urutan paling bawah yang memiliki motivasi belajar rendah. Skor tertinggi diperoleh siswa yang memiliki motivasi belajar tinggi dengan perolehan skor tertinggi 143 dan skor terendah 134, sedangkan skor terendah diperoleh siswa yang memiliki motivasi belajar rendah memperoleh skor tertinggi 121 dan skor terendah 90 . Selanjutnya, dalam penelitian ini terdapat enam kelompok data yang dideskripsikan secara rinci. Keenam kelompok data tersebut dijelaskan sebagai berikut.

Pertama, data keterampilan menulis teks prosedur kelas eksperimen yang dibelajarkan menggunakan model pembelajaran kooperatif tipe Example Non Example dapat dilihat pada Tabel 1. Berdasarkan Tabel 1, dapat dilihat bahwa tes unjuk kerja yang dilakukan di kelas eksperimen dibelajarkan menggunakan model pembelajaran kooperatif tipe Example Non Example diperoleh nilai ratarata sebesar 83,58 dengan jumlah siswa 36 orang. Nilai tertinggi yang diperoleh siswa adalah 94 dengan frekuensi sebanyak 5 orang. Nilai terendah yang diperoleh yang diperoleh siswa adalah 71 dengan frekuensi sebanyak 3 orang. Simpangan baku pada kelas eksperimen adalah 7,18. Kedua, data keterampilan menulis teks prosedur siswa yang memiliki motivasi belajar tinggi di kelas eksperimen dapat dilihat pada Tabel 2.

Tabel 2 menunjukkan bahwa keterampilan menulis teks prosedur siswa yang memiliki motivasi belajar tinggi di kelas eksperimen diperoleh nilai rata-rata sebesar 92,2 dengan jumlah siswa 10 orang. Nilai tertinggi yang diperoleh siswa adalah 94 dengan frekuensi sebanyak 5 orang. Nilai terendah yang diperoleh yang diperoleh siswa adalah 90 dengan frekuensi sebanyak 4 orang. Simpangan baku keterampilan menulis teks prosedur siswa yang memiliki motivasi belajar tinggi di kelas eksperimen adalah 1,99.

Ketiga, data keterampilan menulis teks prosedur siswa yang memiliki motivasi belajar rendah di kelas eksperimen dapat dilihat pada Tabel 3 . Keterampilan menulis teks prosedur siswa yang memiliki motivasi belajar rendah di kelas eksperimen yang terdapat pada Tabel 3 diperoleh nilai rata-rata sebesar 74,2 dengan jumlah siswa 10 orang. Nilai tertinggi yang diperoleh siswa adalah 79 dengan frekuensi sebanyak 1 orang. Nilai terendah yang diperoleh yang diperoleh siswa adalah 71 dengan frekuensi sebanyak 3 orang. Simpangan baku keterampilan menulis teks prosedur siswa yang memiliki motivasi belajar tinggi di kelas eksperimen adalah 2,53.

Keempat, data keterampilan menulis teks prosedur kelas kontrol yang dibelajarkan menggunakan model pembelajaran konvensional dapat dilihat pada 
Tabel 4. Pada Tabel 4 dapat dilihat bahwa tes unjuk kerja yang dilakukan di kelas eksperimen dibelajarkan menggunakan model pembelajaran konvensional diperoleh nilai rata-rata sebesar 72,54 dengan jumlah siswa 37 orang. Nilai tertinggi yang diperoleh siswa adalah 90 dengan frekuensi sebanyak 1 orang. Nilai terendah yang diperoleh yang diperoleh siswa adalah 63 dengan frekuensi sebanyak 3 orang. Simpangan baku pada kelas eksperimen adalah 6,53.

Kelima, data keterampilan menulis teks prosedur siswa yang memiliki motivasi belajar tinggi di kelas kontrol dapat dilihat pada Tabel 5 . Tabel 5 menunjukkan bahwa keterampilan menulis teks prosedur siswa yang memiliki motivasi belajar tinggi di kelas kontrol diperoleh nilai rata-rata sebesar 80,7 dengan jumlah siswa 10 orang. Nilai tertinggi yang diperoleh siswa adalah 90 dengan frekuensi sebanyak 1 orang. Nilai terendah yang diperoleh yang diperoleh siswa adalah 75 dengan frekuensi sebanyak 1 orang. Simpangan baku keterampilan menulis teks prosedur siswa yang memiliki motivasi belajar tinggi di kelas kontrol adalah 4,42.

Keenam, data keterampilan menulis teks prosedur siswa yang memiliki motivasi belajar rendah di kelas kontrol dapat dilihat pada Tabel 6. Keterampilan menulis teks prosedur siswa yang memiliki motivasi belajar rendah di kelas kontrol pada Tabel 6 diperoleh nilai rata-rata sebesar 64,8 dengan jumlah siswa 10 orang. Nilai tertinggi yang diperoleh siswa adalah 67 dengan frekuensi sebanyak 2 orang. Nilai terendah yang diperoleh yang diperoleh siswa adalah 63 dengan frekuensi sebanyak 3 orang. Simpangan baku keterampilan menulis teks prosedur siswa yang memiliki motivasi belajar rendah di kelas kontrol adalah 1,48 .

Tabel 1. Keterampilan Menulis Teks Prosedur Kelas Eksperimen

\begin{tabular}{cccccc}
\hline Kelas & Nilai Tertinggi & Nilai Terendah & $\overline{\boldsymbol{x}}$ & $\mathbf{N}$ & $\mathbf{S}$ \\
\hline Eksperimen & 94 & 71 & 83,58 & 36 & 7,18 \\
\hline
\end{tabular}

Tabel 2. Keterampilan Menulis Teks Prosedur Siswa yang Memiliki Motivasi Belajar Tinggi di Kelas Eksperimen

\begin{tabular}{cccccc}
\hline Kelas & Nilai Tertinggi & Nilai Terendah & $\overline{\boldsymbol{x}}$ & $\mathbf{N}$ & $\mathbf{S}$ \\
\hline Eksperimen & 94 & 90 & 92,2 & 10 & 1,99 \\
\hline
\end{tabular}

Tabel 3. Keterampilan Menulis Teks Prosedur Siswa yang Memiliki Motivasi Belajar Rendah di Kelas Eksperimen

\begin{tabular}{cccccc}
\hline Kelas & Nilai Tertinggi & Nilai Terendah & $\overline{\boldsymbol{x}}$ & $\mathbf{N}$ & $\mathbf{S}$ \\
\hline Eksperimen & 79 & 71 & 74,2 & 10 & 2,53 \\
\hline
\end{tabular}

Tabel 4. Keterampilan Menulis Teks Prosedur Kelas Kontrol

\begin{tabular}{cccccc}
\hline Kelas & Nilai Tertinggi & Nilai Terendah & $\overline{\boldsymbol{x}}$ & $\mathbf{N}$ & $\mathbf{S}$ \\
\hline Eksperimen & 90 & 63 & 72,54 & 37 & 6,53 \\
\hline
\end{tabular}

Tabel 5. Keterampilan Menulis Teks Prosedur Siswa yang Memiliki Motivasi Belajar Tinggi di Kelas Kontrol

\begin{tabular}{cccccc}
\hline Kelas & Nilai Tertinggi & Nilai Terendah & $\overline{\boldsymbol{x}}$ & $\mathbf{N}$ & $\mathbf{S}$ \\
\hline Eksperimen & 90 & 75 & 80,7 & 10 & 4,42 \\
\hline
\end{tabular}


Tabel 6. Keterampilan Menulis Teks Prosedur Siswa yang Memiliki Motivasi Belajar Rendah di Kelas Kontrol

\begin{tabular}{cccccc}
\hline Kelas & Nilai Tertinggi & Nilai Terendah & $\overline{\boldsymbol{x}}$ & $\mathbf{N}$ & $\mathbf{S}$ \\
\hline Eksperimen & 67 & 63 & 64,8 & 10 & 1,48 \\
\hline
\end{tabular}

\section{Uji Persyarat Analisis}

\section{a. Uji Normalitas}

Uji normalitas yang dalam penelitian ini adalah sebagai berikut. Pertama, hasil uji normalitas hasil tes keterampilan menulis teks prosedur siswa kelas eksperimen diuraikan dalam Tabel 7. Hasil tes keterampilan menulis teks prosedur siswa pada kelas eksperimen yang terdapat pada tabel di atas diperoleh $L_{0}$ 0,022, sedangkan $L_{t}$ pada taraf nyata (a) 0,05 adalah 0,153 . Berdasarkan hasil tersebut dapat disimpulkan bahwa $\mathrm{H}_{0}$ diterima. Jadi, data keterampilan menulis teks prosedur siswa pada kelas eksperimen berdistribusi normal karena $L_{0}<L_{t}$.

Kedua, hasil uji normalitas hasil tes keterampilan menulis teks prosedur siswa yang memiliki motivasi belajar tinggi pada kelas eksperimen diuraikan dalam Tabel 8 . Tabel 8 menunjukkan bahwa hasil tes keterampilan menulis teks prosedur siswa yang memiliki motivasi belajar tinggi pada kelas eksperimen memiliki Lo sebesar 0,044, sedangkan $L_{t}$ pada taraf nyata (a) 0,05 adalah 0,285 sehingga dapat dinyatakan bahwa $\mathrm{H}_{0}$ diterima dan keterampilan menulis teks prosedur siswa yang memiliki motivasi belajar tinggi pada kelas eksperimen berdistribusi normal.

Ketiga, hasil uji normalitas hasil tes keterampilan menulis teks prosedur siswa yang memiliki motivasi belajar tinggi pada kelas eksperimen diuraikan dalam Tabel 9. Hasil tes keterampilan menulis teks prosedur siswa yang memiliki motivasi belajar tinggi pada kelas eksperimen memiliki Lo sebesar -0,273, sedangkan $L_{t}$ pada taraf nyata (a) 0,05 adalah 0,285 sehingga dapat dinyatakan bahwa $\mathrm{H}_{0}$ diterima dan keterampilan menulis teks prosedur siswa yang memiliki motivasi belajar rendah pada kelas eksperimen berdistribusi normal.

Keempat, hasil uji normalitas hasil tes keterampilan menulis teks prosedur siswa pada kelas kontrol juga diuraikan dalam Tabel 10. Tabel 10 menunjukkan bahwa hasil tes keterampilan menulis teks prosedur siswa pada kelas kontrol memiliki Lo sebesar 0,001, sedangkan $L_{t}$ pada taraf nyata (a) 0,05 adalah 0,151 sehingga dapat dinyatakan bahwa $\mathrm{H}_{0}$ diterima dan keterampilan menulis teks prosedur siswa pada kelas kontrol berdistribusi normal.

Kelima, hasil uji normalitas hasil tes keterampilan menulis teks prosedur siswa yang memiliki motivasi belajar tinggi pada kelas kontrol juga diuraikan dalam Tabel 11. Pada Tabel 11 ditunjukkan bahwa hasil tes keterampilan menulis teks prosedur siswa yang memiliki motivasi belajar tinggi pada kelas eksperimen memiliki $L_{0}$ sebesar $-0,038$, sedangkan $L_{t}$ pada taraf nyata (a) 0,05 adalah 0,285 sehingga dapat dinyatakan bahwa $\mathrm{H}_{0}$ diterima dan keterampilan menulis teks prosedur siswa yang memiliki motivasi belajar tinggi pada kelas eksperimen berdistribusi normal. 
Keenam, hasil uji normalitas hasil tes keterampilan menulis teks prosedur siswa yang memiliki motivasi belajar renda pada kelas kontrol juga diuraikan dalam Tabel 12. Pada Tabel 12 dinyatakan bahwa hasil tes keterampilan menulis teks prosedur siswa yang memiliki motivasi belajar rendah pada kelas eksperimen memiliki $L_{0}$ sebesar 0,058 , sedangkan $L_{t}$ pada taraf nyata (a) 0,05 adalah 0,285 sehingga dapat dinyatakan bahwa $\mathrm{H}_{0}$ diterima dan keterampilan menulis teks prosedur siswa yang memiliki motivasi belajar rendah pada kelas eksperimen berdistribusi normal.

Tabel 7. Uji Normalitas Data Keterampilan Menulis Teks Prosedur Siswa pada Kelas Eksperimen

\begin{tabular}{|c|c|c|c|c|c|}
\hline No. & Sampel & $\mathbf{A}$ & $\mathrm{L}_{0}$ & $L_{t}$ & Keterangan \\
\hline 1 & $\begin{array}{ll}\text { Kelas Eksperimen } & N=36 \\
& \bar{X}=83,58 \\
& X_{i}=3009 \\
& X_{i}^{2}=253307 \\
& S^{2}=51,55 \\
& S=7,18\end{array}$ & 0,05 & 0,022 & 0,153 & Normal \\
\hline
\end{tabular}

Tabel 8. Uji Normalitas Data Keterampilan Menulis Teks Prosedur Siswa yang Memiliki Motivasi Belajar Tinggi pada Kelas Eksperimen

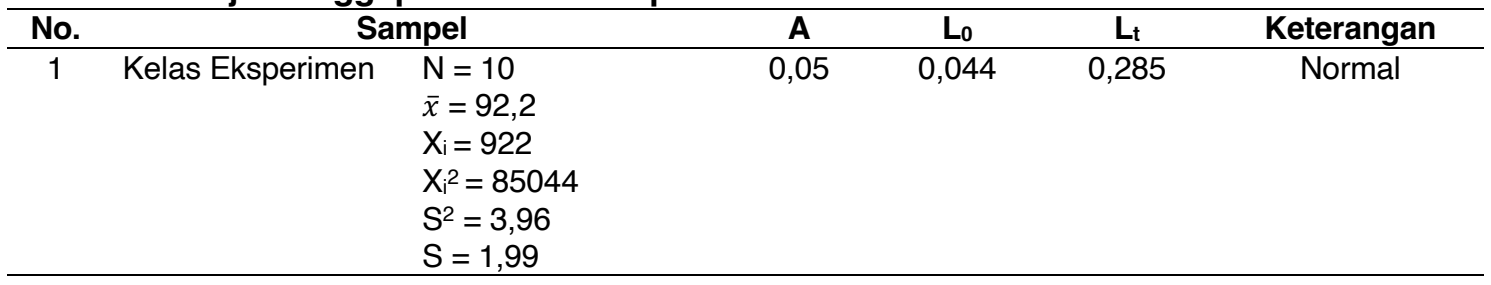

Tabel 9. Uji Normalitas Data Keterampilan Menulis Teks Prosedur Siswa yang Memiliki Motivasi Belajar Rendah pada Kelas Eksperimen

\begin{tabular}{|c|c|c|c|c|c|c|}
\hline No. & & ipel & $\mathbf{A}$ & $L_{0}$ & $L_{t}$ & Keterangan \\
\hline 1 & Kelas Eksperimen & $\begin{array}{l}N=10 \\
\bar{x}=74,2 \\
X_{i}=742 \\
X_{i}^{2}=55114 \\
S^{2}=6,40 \\
S=2,53\end{array}$ & 0,05 & 0,273 & 0,285 & Normal \\
\hline
\end{tabular}

Tabel 10. Uji Normalitas Data Keterampilan Menulis Teks Prosedur Siswa pada Kelas Kontrol

\begin{tabular}{ccccccc}
\hline No. & Sampel & A & L $_{0}$ & $\mathbf{L}_{\mathbf{t}}$ & Keterangan \\
\hline 1 & Kelas Kontrol & $\mathrm{N}=37$ & 0,05 & 0,001 & 0,151 & Normal \\
& $\overline{\mathrm{X}}=72,54$ & & & & \\
& $\mathrm{X}_{\mathrm{i}}=2684$ & & & & \\
& $\mathrm{X}^{2}=196232$ & & & & \\
& $\mathrm{~S}^{2}=42,64$ & & & & \\
& $\mathrm{~S}=6,53$ & & & & \\
& & & & & \\
\hline
\end{tabular}


Tabel 11. Uji Normalitas Data Keterampilan Menulis Teks Prosedur Siswa yang Memiliki Motivasi Belajar Tinggi pada Kelas Kontrol

\begin{tabular}{|c|c|c|c|c|c|c|}
\hline No. & & npel & $\mathbf{A}$ & $L_{0}$ & $L_{t}$ & Keterangan \\
\hline 1 & Kelas Kontrol & $\begin{array}{l}\mathrm{N}=10 \\
\bar{x}=80,7 \\
X_{i}=807 \\
X_{i}^{2}=65301 \\
S^{2}=19,54 \\
S=4,42\end{array}$ & 0,05 & 0,038 & 0,285 & Normal \\
\hline
\end{tabular}

Tabel 12. Uji Normalitas Data Keterampilan Menulis Teks Prosedur Siswa yang Memiliki Motivasi Belajar Rendah pada Kelas Kontrol

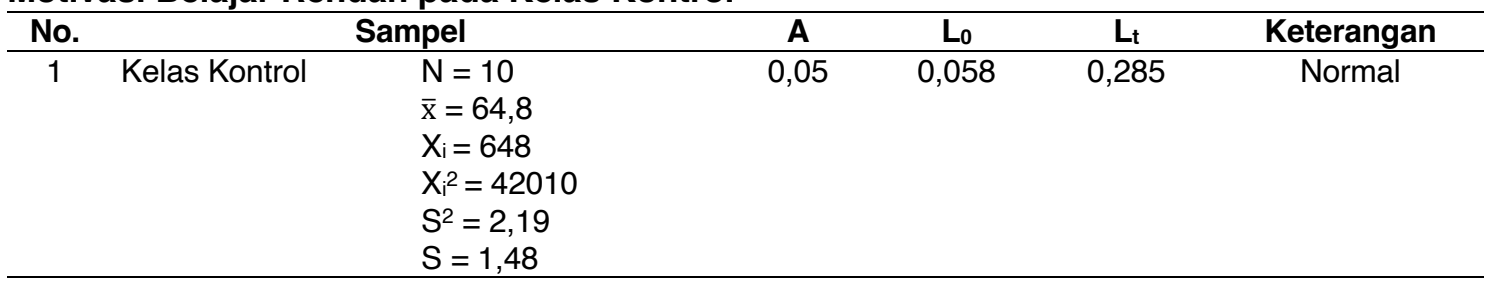

\section{b. Uji Homogenitas}

Uji homogenitas dalam penelitian ini, yaitu pertama, hasil uji homogenitas data hasil tes keterampilan menulis teks prosedur siswa pada kelas eksperimen dan kelas kontrol disajikan dalam Tabel 13. Hasil varians terbesar pada kelas eksperimen adalah 51,55 dan varians terkecil pada kelas kontrol adalah 42,64. $F_{h}$ yang diperoleh dari kedua kelas tersebut adalah 1,21, sedangkan $F_{t}$ yang diperoleh adalah 1,75 sehingga dapat disimpulkan bahwa data hasil tes keterampilan menulis teks prosedur siswa pada kelas eksperimen dan kelas kontrol memiliki varians homogen karena $\mathrm{F}_{\mathrm{h}}<\mathrm{F}_{\mathrm{t}}$.

Kedua, hasil uji homogenitas data hasil tes keterampilan menulis teks prosedur siswa yang memiliki motivasi belajar tinggi pada kelas eksperimen dan kelas kontrol disajikan dalam Tabel 13. Hasil varians terbesar pada kelas eksperimen adalah 3,96 dan varians terkecil pada kelas kontrol adalah 19,54. $\mathrm{F}_{\mathrm{h}}$ yang diperoleh dari kedua kelas tersebut adalah 0,20 , sedangkan $F_{t}$ yang diperoleh adalah 3,18 sehingga dapat disimpulkan bahwa data hasil tes keterampilan menulis teks prosedur siswa yang memiliki motivasi belajar tinggi pada kelas eksperimen dan kelas kontrol memiliki varians homogen karena $\mathrm{F}_{\mathrm{h}}<$ $\mathrm{F}_{\mathrm{t} .}$

Ketiga, hasil uji homogenitas data hasil tes keterampilan menulis teks prosedur siswa yang memiliki motivasi belajar rendah pada kelas eksperimen dan kelas kontrol disajikan dalam Tabel 15. Hasil varians terbesar pada kelas eksperimen adalah 6,40 dan varians terkecil pada kelas kontrol adalah 2,19. $\mathrm{Fh}$ yang diperoleh dari kedua kelas tersebut adalah 2,92, sedangkan $F_{t}$ yang diperoleh adalah 3,18 sehingga dapat disimpulkan bahwa data hasil tes keterampilan menulis teks prosedur siswa yang memiliki motivasi belajar rendah pada kelas eksperimen dan kelas kontrol memiliki varians homogen karena $\mathrm{F}_{\mathrm{h}}<$ $\mathrm{F}_{\mathrm{t} .}$ 
Tabel 13. Uji Homogenitas Keterampilan Menulis Teks Prosedur Siswa pada Kelas Eksperimen dan Kelas Kontrol

\begin{tabular}{ccccccc}
\hline No. & Sampel & $\mathbf{N}$ & $\mathbf{S}^{2}$ & $\mathbf{F}_{\mathbf{h}}$ & $\mathbf{F}_{\mathbf{t}}$ & Keterangan \\
\hline 1 & Kelas Eksperimen & 36 & 51,55 & 1,21 & 1,75 & Homogen \\
2 & Kelas Kontrol & 37 & 42,64 & & & \\
\hline
\end{tabular}

Tabel 14. Uji Homogenitas Keterampilan Menulis Teks Prosedur Siswa yang pada Kelas Eksperimen dan Kelas Kontrol

\begin{tabular}{ccccccc}
\hline No. & Sampel & $\mathbf{N}$ & $\mathbf{S}^{2}$ & $\mathbf{F}_{\mathbf{h}}$ & $\mathbf{F}_{\mathbf{t}}$ & Keterangan \\
\hline 1 & Kelas Eksperimen & 10 & 3,96 & 0,20 & 3,18 & Homogen \\
2 & Kelas Kontrol & 10 & 19,54 & & & \\
\hline
\end{tabular}

Tabel 15. Uji Homogenitas Keterampilan Menulis Teks Prosedur Siswa yang pada Kelas Eksperimen dan Kelas Kontrol

\begin{tabular}{ccccccc}
\hline No. & Sampel & $\mathbf{N}$ & $\mathbf{S}^{2}$ & $\mathbf{F}_{\mathbf{h}}$ & $\mathbf{F}_{\mathbf{t}}$ & Keterangan \\
\hline 1 & Kelas Eksperimen & 10 & 6,40 & 2,92 & 3,18 & Homogen \\
2 & Kelas Kontrol & 10 & 2,19 & & & \\
\hline
\end{tabular}

\section{c. Uji Hipotesis}

Uji hipotesis yang dilakukan dalam penelitian ini adalah uji hipotesis 1, 2, 3, dan 4. Keempat hasil uji hipotesis tersebut adalah sebagai berikut. Pertama, hasil uji hipotesis 1 disajikan dalam Tabel 16. Hasil uji hipotesis 1 pada tabel 16 diperoleh thitung $=6,99$ pada taraf $\mathrm{a}=0,05$ dan $d k=\left(n_{1}+n_{2}\right)-2$ diperoleh tabel $=1,64$. Artinya, thitung $>$ tabel. Hal ini dapat disimpulkan bahwa rata-rata nilai tes keterampilan menulis teks prosedur siswa yang diajar menggunakan model pembelajaran kooperatif tipe Example Non Example lebih tinggi daripada ratarata keterampilan menulis teks prosedur yang diajar menggunakan model pembelajaran konvensional.

Kedua, hasil uji hipotesis 2 disajikan dalam Tabel 17. Hasil uji hipotesis 2 pada Tabel 17 diperoleh thitung $=7,71$ pada taraf $a=0,05$ dan $d k=\left(n_{1}+n_{2}\right)-2$ diperoleh tabel $=1,81$. Artinya, thitung $>t_{\text {tabel. }}$. Hal ini dapat disimpulkan bahwa ratarata nilai tes keterampilan menulis teks prosedur siswa yang memiliki motivasi belajar tinggi yang diajar menggunakan model pembelajaran kooperatif tipe Example Non Example lebih tinggi daripada rata-rata keterampilan menulis teks prosedur siswa yang memiliki motivasi belajar tinggi yang diajar menggunakan model pembelajaran konvensional.

Ketiga, hasil uji hipotesis 3 disajikan dalam Tabel 18. Hasil uji hipotesis 3 pada Tabel 18 diperoleh thitung $=10,11$ pada taraf $a=0,05$ dan $d k=\left(n_{1}+n_{2}\right)-$ 2 diperoleh $t_{\text {tabel }}=1,81$. Artinya, thitung $>t_{\text {tabel. }}$. Hal ini dapat disimpulkan bahwa rata-rata nilai tes keterampilan menulis teks prosedur siswa yang memiliki motivasi belajar rendah yang diajar menggunakan model pembelajaran kooperatif tipe Example Non Example lebih tinggi daripada rata-rata keterampilan menulis teks prosedur siswa yang memiliki motivasi belajar rendah yang diajar menggunakan model pembelajaran konvensional. 
Tabel 16. Hasil Uji Hipotesis 1 dengan Uji $t$

\begin{tabular}{ccc}
\hline Keterangan & Eksperimen & Kontrol \\
\hline $\mathrm{N}$ & 36 & 37 \\
$\overline{\mathrm{x}}$ & 83,58 & 72,54 \\
$\mathrm{~S}^{2}$ & 51,55 & 42,64 \\
$\mathrm{t}_{\text {hitung }}$ & & 6,99 \\
$\mathrm{t}_{\text {tabel }}$ & & 1,64 \\
\hline
\end{tabular}

Tabel 17. Hasil Uji Hipotesis 2 dengan Uji t

\begin{tabular}{ccc}
\hline Keterangan & Eksperimen & Kontrol \\
\hline $\mathrm{N}$ & 10 & 10 \\
$\overline{\mathrm{x}}$ & 92,2 & 80,7 \\
$\mathrm{~S}^{2}$ & 3,96 & 19,54 \\
thitung & & 7,71 \\
ttabel & & 1,81 \\
\hline
\end{tabular}

Tabel 18. Hasil Uji Hipotesis 3 dengan Uji t

\begin{tabular}{ccc}
\hline Keterangan & Eksperimen & Kontrol \\
\hline $\mathrm{N}$ & 10 & 10 \\
$\overline{\mathrm{x}}$ & 74,2 & 64,8 \\
$\mathrm{~S}^{2}$ & 6,40 & 2,19 \\
thitung & & 10,11 \\
tabel & & 1,81 \\
\hline
\end{tabular}

Tabel 19. Hasil Uji Hipotesis 4 dengan Anava Dua Arah

\begin{tabular}{lccccc}
\hline $\begin{array}{c}\text { Sumber } \\
\text { Varians }\end{array}$ & $\begin{array}{c}\text { Jumlah Kuadrat } \\
(\mathbf{J K})\end{array}$ & $\begin{array}{c}\text { Derajat } \\
\text { Kebebasan } \mathbf{( d b )}\end{array}$ & $\begin{array}{c}\text { Rataan Kuadrat } \\
\text { (MK=JK/db) }\end{array}$ & F $_{\text {hitung }}$ & F $_{\text {tabel }}$ \\
\hline Antar Baris & $\mathrm{JK}_{\mathrm{A}}=1092$ & 1 & 1092 & 136,03 & 4,10 \\
Antar Kolom & $\mathrm{JK}_{\mathrm{B}}=1092$ & 1 & 1092 & 136,03 & 4,10 \\
Interaksi & $\mathrm{JK}_{\mathrm{AB}}=1792$ & 1 & 1792 & 223,2 & 4,10 \\
Dalam & $\mathrm{JK}_{\mathrm{DAT}}=289$ & 36 & 8,03 & - & - \\
Jumlah & 4265 & 39 & - & - & - \\
\hline
\end{tabular}

Keempat, uji hipotesis 4 yang bertujuan untuk mengetahui interaksi antara model pembelajaran kooperatif tipe Example Non Example dan motivasi belajar siswa terhadap keterampilan menulis teks prosedur siswa. Selanjutnya hasil uji hipotesis 4 juga disajikan dalam Tabel 19. Pada Tabel 19 terlihat hasil uji hipotesis 4 diperoleh $F_{\text {hitung }}=223,2$ pada taraf $a=0,05$ diperoleh $F_{\text {tabel }} 4,10$. Artinya $\mathrm{H}_{0}$ ditolak dan $\mathrm{H}_{1}$ diterima. Hal ini dapat disimpulkan bahwa terjadi interaksi antara model pembelajaran kooperatif tipe Example Non Example dengan motivasi belajar siswa dalam mempengaruhi keterampilan menulis teks prosedur siswa.

Berdasarkan hasil uji hipotesis 1, dapat diketahui bahwa secara keseluruhan keterampilan menulis teks prosedur siswa yang diajar menggunakan model pembelajaran kooperatif tipe Example Non Example lebih tinggi daripada keterampilan menulis teks prosedur yang diajar menggunakan model pembelajaran konvensional sehingga nilai keterampilan menulis teks prosedur siswa pada kelas eksperimen juga lebih tinggi daripada nilai yang diperoleh siswa pada kelas kontrol. Hal ini dapat dibuktikan bahwa sudah banyak siswa di kelas eksperimen yang memperoleh nilai di atas Kriteria Belajar Minimal (KBM) di MTs Negeri 4 Pasaman Barat, yaitu 75. Siswa yang memperoleh nilai di atas Kriteria Belajar Minimal (KBM) yang diajarkan menggunakan model pembelajaran 
Example Non Example pada kelas eksperimen sebanyak 33 orang, sedangkan 3 orang siswa tidak tuntas.

Pada kelas kontrol diberikan perlakuan dengan menggunakan model pembelajaran konvensional, yaitu berupa komunikasi satu arah. Pembelajaran ini dilakukan oleh guru dengan cara memberikan penjelasan atau menyampaikan materi pelajaran kepada siswa secara lisan. Oleh karena itu, pembelajaran konvensional menyebabkan aktivitas di kelas didominasi oleh guru, sedangkan siswa bersifat pasif selama proses pembelajaran sehingga menyebabkan siswa cenderung bosan dan kurang bersemangat menerima materi dari guru. Hal ini sejalan dengan pendapat Sanjaya (2012, hal. 259) bahwa model pembelajaran konvensional adalah model pembelajaran yang perannya didominasi oleh guru dan murid menerima informasi secara pasif.

Selain itu, model pembelajaran konvensional yang diterapkan tidak memiliki pengaruh yang signifikan terhadap peningkatan keterampilan menulis teks prosedur siswa. Hal ini dapat dibuktikan berdasarkan nilai yang diperoleh siswa pada kelas kontrol masih banyak yang berada di bawah Kriteria Belajar Minimal (KBM), yaitu 75. Jumlah siswa pada kelas kontrol yang diajar dengan model pembelajaran konvensional yang memperoleh nilai di atas Kriteria Belajar Minimal (KBM) sebanyak 15 orang, sedangkan yang memperoleh nilai di bawah Kriteria Belajar Minimal (KBM) sebanyak 22 orang. Berdasarkan hasil temuan dan analisis data yang telah dilakukan dapat disimpulkan bahwa teori pada bab 2 yang digunakan dalam penelitian ini adalah benar. Selanjutnya, berdasarkan analisis data tersebut juga dibuktikan bahwa hasil tes keterampilan menulis teks prosedur siswa kelas eksperimen yang diajar dengan model pembelajaran kooperatif tipe Example Non Example lebih tinggi daripada kelas kontrol yang diajar dengan model pembelajaran konvensional sehingga dapat disimpulkan terdapat pengaruh penggunaan model pembelajaran kooperatif Example Non Example terhadap keterampilan menulis teks prosedur siswa.

Berdasarkan hasil uji hipotesis 2, dapat diketahui bahwa keterampilan menulis teks prosedur siswa yang memiliki motivasi belajar tinggi yang diajar menggunakan model pembelajaran kooperatif tipe Example Non Example lebih baik daripada keterampilan menulis teks prosedur siswa yang memiliki motivasi belajar tinggi yang diajar menggunakan model pembelajaran konvensional. Hal ini menyebabkan nilai yang diperoleh siswa pada kelas eksperimen lebih tinggi daripada nilai yang diperoleh siswa pada kelas kontrol.

Selanjutnya, penggunaan model pembelajaran kooperatif Example Non Example dan motivasi belajar tinggi pada siswa memiliki pengaruh terhadap keterampilan menulis teks prosedur siswa tersebut. Hal ini dapat dilihat dari nilai yang diperoleh siswa yang memiliki motivasi belajar tinggi di kelas eksperimen lebih tinggi daripada siswa yang memiliki motivasi belajar tinggi di kelas kontrol. Siswa pada kelas eksperimen memperoleh nilai rata-rata 92,2, sedangkan siswa pada kelas kontrol memperoleh nilai rata-rata 80,7 sehingga dapat dikatakan bahwa teori yang digunakan cocok dalam penelitian ini. Sementara itu, siswa pada kelas kontrol hanya menerima informasi dari satu arah, yaitu guru. Berdasarkan perbedaan rata-rata nilai pada kedua kelas tersebut, dapat disimpulkan bahwa semakin tinggi motivasi belajar yang dimiliki siswa, maka 
semakin tinggi pula minat dan kemampuan siswa dalam mengembangkan ide dan gagasan ketika menulis teks prosedur baik secara individu maupun secara berkelompok.

Berdasarkan hasil uji hipotesis 3, dapat diketahui bahwa keterampilan menulis teks prosedur siswa yang memiliki motivasi belajar rendah yang diajar menggunakan model pembelajaran kooperatif tipe Example Non Example lebih baik daripada keterampilan menulis teks prosedur siswa yang memiliki motivasi belajar rendah yang diajar menggunakan model pembelajaran konvensional. Hal ini juga menyebabkan nilai yang diperoleh siswa pada kelas eksperimen lebih tinggi daripada nilai yang diperoleh siswa pada kelas kontrol. Siswa pada kelas eksperimen memperoleh nilai rata-rata 74,2 , sedangkan siswa pada kelas kontrol memperoleh nilai rata-rata 64,8 . Berdasarkan perbedaan nilai rata-rata tersebut, dapat disimpulkan bahwa siswa yang memiliki motivasi belajar rendah pada kelas kontrol mengalami kesulitan dalam menulis teks prosedur. Hal ini dikarenakan siswa tersebut diajar menggunakan model pembelajaran konvensional yang didominasi oleh guru sehingga siswa cenderung pasif dan tidak dapat mengembangkan ide atau gagasannya dengan baik serta menyebabkan nilai yang diperoleh masih rendah. Permasalahan ini juga ditemukan dalam penelitian (Aminah, 2020) bahwa siswa model pembelajaran konvensional menyebabkan rendahnya minat siswa dalam menulis teks prosedur sehingga siswa tersebut tidak mampu menulis teks prosedur dengan baik. Selanjutnya, dalam mengatasi permasalahan siswa dalam menulis tek prosedur ini perlu dilakukan upaya-upaya yang dapat meningkatkan minat, semangat, dan motivasi siswa dalam belajar, khususnya pembelajaran menulis teks prosedur.

Berdasarkan hasil uji hipotesis 4, dapat dilihat perbedaan rata-rata di kelas eksperimen dan kelas kontrol. Siswa yang memiliki motivasi belajar tinggi yang diajar dengan menggunakan model pembelajaran kooperatif tipe Example Non Example memperoleh rata-rata 92,2, sedangkan siswa yang memiliki motivasi belajar tinggi yang diajar dengan menggunakan model pembelajaran konvensional memperoleh rata-rata 80,7. Siswa yang memiliki motivasi belajar rendah yang diajar dengan menggunakan model pembelajaran kooperatif tipe Example Non Example memperoleh rata-rata 74,2, sedangkan siswa yang memiliki motivasi belajar rendah yang diajar dengan menggunakan model pembelajaran konvensional memperoleh rata-rata 64,8. Dari sisi kolom adanya interaksi memberi arti bahwa pada model pembelajaran kooperatif tipe Example Non Example antara siswa yang memiliki motivasi belajar dan motivasi belajar rendah terdapat perbedaan dalam keterampilan menulis teks prosedur dan hal yang sama berlaku pada kelas eksperimen yang diajar dengan menggunakan model pembelajaran konvensional.

Salah satu upaya untuk meningkatkan hasil belajar siswa adalah dengan cara meningkatkan minat dan motivasi siswa dalam mempelajari suatu pembelajaran. Dalam hal ini, guru dapat memilih metode atau model pembelajaran yang tepat dengan materi pelajaran yang sedang dibahas sehingga guru dalam melihat sejauh mana motivasi yang dimiliki oleh masingmasing siswa. Hal tersebut juga dijelaskan dalam penelitian Muhammad bahwa siswa yang memiliki motivasi belajar yang tinggi akan memperoleh hasil belajar 
yang lebih baik dibanding dengan siswa yang memiliki motivasi belajar rendah (Muhammad, 2016).

Berdasarkan penjelasan tersebut, dapat disimpulkan bahwa siswa yang memiliki motivasi belajar tinggi dapat belajar dengan menggunakan model pembelajaran kooperatif tipe Example Non Example untuk meningkatkan keterampilan menulis teks prosedur, sedangkan siswa yang memiliki motivasi belajar rendah dapat belajar dengan cara memilih metode belajar yang tepat dan mudah dipahami oleh masing-masing siswa.

\section{Penutup}

Penelitian ini membahas pengaruh model pembelajaran Example Non Example dan motivasi belajar terhadap keterampilan menulis teks prosedur siswa kelas VII MTs Negeri 4 Pasaman Barat. Berdasarkan deskripsi, analisis, dan pembahasan terhadap data penelitian yang telah dilakukan, dapat disimpulkan empat hal berikut. Pertama, keterampilan menulis teks prosedur siswa yang diajar dengan menggunakan model pembelajaran kooperatif tipe Example Non Example lebih baik daripada siswa yang diajar menggunakan model pembelajaran konvensional. Kedua, keterampilan menulis teks prosedur siswa yang memiliki motivasi belajar tinggi yang diajar dengan menggunakan model pembelajaran kooperatif tipe Example Non Example lebih baik daripada siswa yang memiliki motivasi belajar tinggi yang diajar menggunakan model pembelajaran konvensional. Ketiga, keterampilan menulis teks prosedur siswa yang memiliki motivasi belajar rendah yang diajar dengan menggunakan model pembelajaran kooperatif tipe Example Non Example lebih baik daripada siswa yang memiliki motivasi belajar rendah yang diajar menggunakan model pembelajaran konvensional. Keempat, terdapat interaksi antara model pembelajaran Example Non Example dengan motivasi belajar.

\section{Daftar Pustaka}

Aminah, S. (2020). Pembelajaran Menulis Teks Prosedur Dengan Model "Picture and Picture." Dinamika: Jurnal Bahasa, Sastra, dan Pembelajarannya, 3(1), 34-42. https://doi.org/10.35194/jd.v3i1.999

Anh, D. T. N. (2019). EFL Student's Writing Skills: Challenges and Remedies. IOSR Journal of Research \& Method in Education (IOSR-JRME), 9(6), 7484. Diambil dari https://iosrjournals.org/iosr-jrme/papers/Vol-9\%20lssue6/Series-1/J0906017484.pdf

Devi, P. C., Hudiyono, Y., \& Mulawarman, W. G. (2018). Pengembangan Bahan Ajar Menulis Teks Prosedur Kompleks dengan Model Pembelajaran Discovery Learning Menggunakan Media Audio Visual (Video) di Kelas XI SMA Negeri 1 Samarinda. Diglosia: Jurnal Kajian Bahasa, Sastra, dan Pengajarannya, 1(2), 101-114. https://doi.org/10.30872/diglosia.v1i2.13

Hapsari, T. P. R. N., \& Wulandari, A. (2020). Analisis Kelayakan Buku Ajar Milenial Berbasis Augmented Reality (AR) sebagai Media Pembelajaran Teks Prosedur di Magelang. Diglosia: Jurnal Kajian Bahasa, Sastra, dan 
Pengajarannya, 3(4), 351-364. https://doi.org/10.30872/diglosia.v3i4.125 Hidayat, M. T. (2020). Pembelajaran Menulis Teks Prosedur dengan Metode Discovery Learning pada Siswa Kelas VII SMP Negeri 1 Langsa. Jurnal Samudra Bahasa, 3(1), 45-51. https://doi.org/10.33059/jsb.v3i1.2208

Javed, M., Juan, W. X., \& Nazli, S. (2013). A Study of Students' Assessment in Writing Skills of the English Language. International Journal of Instruction, 6(2), 1308-1470. Diambil dari https://www.eiji.net/dosyalar/iji_2013_2_9.pdf

Kartikasari, R. D., \& Khotimah, D. H. (2018). Pengaruh Media Audiovisual terhadap Keterampilan Menulis Teks Prosedur Kompleks. Seminar Nasional Pendidikan Era Revolusi "Membangun Sinergitas dalam Penguatan Pendidikan Karakter pada Era IR 4.0," 235-240. Diambil dari https://jurnal.umj.ac.id/index.php/SNP/article/view/2774

Karunasree, K., \& Francis, S. (2020). Developing Writing Skills of ESL Learners Using Task Based Language Teaching. Journal of Critical Reviews, 7(06), 6-8. https://doi.org/10.31838/jcr.07.06.02

Lestari, D. W., Dian, H., \& Sudrajat, R. T. (2018). Pembelajaran Menulis Teks Prosedur dengan Menggunakan Metode CTL (Contextual Teaching and Learning) pada Siswa Kelas X MAN Cimahi. PAROLE (Jurnal Pendidikan Bahasa dan Sastra Indonesia), 1(5), 815-820. Diambil dari https://journal.ikipsiliwangi.ac.id/index.php/parole/article/view/333

Mandasari, W. A., Atmazaki, \& Noveria, E. (2017). Pengaruh Model Project Based Learning Berbantuan Media Gambar terhadap Keterampilan Menulis Teks Prosedur. Jurnal Pendidikan Bahasa dan Sastra Indonesia, 6(2), 401408. https://doi.org/10.24036/8667-019883

Muhammad, M. (2016). Pengaruh Motivasi dalam Pembelajaran. Lantanida Journal, 4(2), 87-97. https://doi.org/10.22373/lj.v4i2.1881

Muslim, I. M. (2014). Helping EFL Students Improve their Writing. International Journal of Humanities and Social Science, 4(2), 105-112. Diambil dari https://citeseerx.ist.psu.edu/viewdoc/download?doi=10.1.1.1085.2418\&rep $=$ rep $1 \&$ type $=$ pdf

Nawawi, Rahmayanti, I., \& Kasih, I. T. (2018). Pengaruh Model Pembelajaran Example Non Example terhadap Kemampuan Menulis Puisi Siswa Kelas X SMK Jakarta Manajemen. Jurnal IMAJERI, 1(1), 101-109. Diambil dari https://journal.uhamka.ac.id/index.php/imajeri/article/view/5071/1817

Negari, G. M. (2011). A Study on Strategy Instruction and EFL Learners' Writing Skill. International Journal of English Linguistics, 1(2), 299-307. https://doi.org/10.5539/ijel.v1n2p299

Oktiani, I. (2017). Kreativitas Guru dalam Meningkatkan Motivasi Belajar Peserta Didik. Jurnal Kependidikan, 5(2), 216-232. https://doi.org/10.24090/jk.v5i2.1939

Queroda, P. G. (2018). Theme writing skills of Pangasinan State University (PSU) education students. TESOL International Journal, 13(3), 31-44. Diambil dari https://files.eric.ed.gov/fulltext/EJ1247311.pdf

Sanjaya, W. (2012). Strategi Pembelajaran Berorientasi Standar Proses Pendidikan. Jakarta: Kencana. 
Sauri, S. (2018). Pengaruh Model Pembelajaran Examples Non Examples terhadap Kemampuan Menulis Surat Resmi pada Siswa Kelas VIII SMP Negeri 1 Bojong, Pandeglang. Jurnal Artikula, 1(1), 29-38. https://doi.org/10.30653/006.201811.4

Suprihatin, S. (2015). Upaya Meningkatkan Motivasi Belajar Siswa. Jurnal Pendidikan Ekonomi UM Metro, 3(1), 73-82. https://doi.org/10.31316/g.couns.v3i1.89

Suryana, R. (2017). Pengaruh Penggunaan Model Examples Non Examples terahadap Keterampilan Menulis Karangan Narasi SDN Siayuh Kecamatan Kelumpang Barat Kabupaten Kotabaru. Cendikia, 5(2), 1-8. Diambil dari https://ejurnal.stkip-ktb.ac.id/index.php/jurnal/article/view/56/46

Utama, S. (2019). Menulis Teks Berbentuk Procedure Melalui Model Pembelajaran Make a Match. SAP (Susunan Artikel Pendidikan), 4(1), 8287. https://doi.org/10.30998/sap.v4i1.4113

Wahyuni, P. D., Djatmika, E. T., \& As'sari, A. R. (2018). Pengaruh Full Day School dan Gerakan Literasi Sekolah terhadap Hasil Belajar dengan Mediasi Motivasi Belajar. Jurnal Pendidikan: Teori, Penelitian, \& Pengembangan, 3(5), 679-684. Diambil dari http://journal.um.ac.id/index.php/jptpp/article/view/11096

Zurita, I., Thahar, H. E., \& Thamsin, A. C. (2017). Pengaruh Teknik Copy the Master terhadap Keterampilan Menulis Teks Prosedur Siswa Kelas VII MTs Negeri Lubuk Buaya Kota Padang. Jurnal Pendidikan Bahasa dan Sastra Indonesia, 6(2), 167-174. Diambil dari http://ejournal.unp.ac.id/index.php/pbs/article/view/8638 
L. M. Putri \& S. Ramadhan 